\title{
Needs Analysis of Creating an Android-Based for Istim $\bar{a}^{-}$Learning Materials
}

\author{
Ihwan Rahman Bahtiar* \\ Universitas Negeri Jakarta, Indonesia
}

\section{E-Mail Address}

ihwanrb@unj.ac.id

${ }^{*}$ Corresponding Author

\begin{abstract}
The growing users of Android-based devices among students and demands the implementation of online learning to encourage innovation in the preparation of learning. One of the innovations following these conditions is the preparation of teaching materials based on Android. The purpose of this study is to find out of needs analysis of Android-Based learning materials for istima $\bar{a}^{c}$ (lisetening) III in Arabic Language Education Study Program, Faculty of Languages and Arts, Universitas Negeri Jakarta. The study analyses the student needs using the descriptive method. While the data will be collected questionnaire. Then, the data analyzed with a quantitative technique. There are three steps of the process that will go through, namely data reduction, data display, and taking a conclusion. The sample of this study was 40 fifth semester students. The result of the study shows that all students own and use based on Android smartphones and students want istima $\bar{a}^{-}$III materials to build in the based-on Android application.
\end{abstract}

\section{Keywords}

Online learning;

Android;

learning materials;

istimā

\section{Introduction}

Distribution of a more extensive internet network and development of android technology creates new cultures. The Cultures created from these two things are practicality and simplicity. At present, we only use devices to order transportation, shop, pay bills, and even consult with doctors. These new cultures have an impact on the learning process. The demand for the composing of Androidbased learning materials that can be accessed with gadgets cannot be denied anymore.

Based on a distributed questionnaire to 22 (samples) of students who have studied the istima $\bar{a}$ (listening) III study, as many as $95.5 \%$ stated that it was time for teaching materials to be presented in an application. 95.5\% stated they agree if the application is used is based on Android. 86.4\% stated that the presentation of istima $\bar{a}^{-}$learning materials in the form of an android-based application is a necessity at this time. Moreover, 95.5\% stated that they could access specific teaching material 'if the teaching material was presented in the form of an android-based application.

In addition to the reasons for students' demands, as illustrated in the results of the questionnaire above, there are several other reasons why it is time for instructional materials to be packed in the form of an Android-based application. First, the use of information and communication technology 
to improve learning efficiency and effectiveness is mandated by Permendikbud No. 22 of 2016, which must be run by educators (Kementerian Pendidikan dan Kebudayaan Republik Indonesia, 2016).

Second, smartphone users in Indonesia reached 355.5 million with 150 million internet users, meaning that $50 \%$ of smartphone users are also active internet users (Indonesia digital, 2019). Third, Android is still the most widely used operating system in the wosrld, with a percentage of $40.06 \%$ of all operating systems used (Bennet, 2020). Fourth, according to a BBC Indonesia report, more than two-thirds of Indonesian students (67\%) use smartphones in the classroom and even more use them to do homework (81\%) (Pelajar Indonesia, 2019). The number of smartphone and android users in Indonesia, especially at the age of the learner, has not been maximally utilized by educators to create teaching materials, learning media, and other learning applications packaged in android-based products.

Several previous studies have shown that Android-based teaching materials have a positive impact on language learning. Android-based Arabic teaching materials help beginner learners in learning Arabic because Android-based teaching materials are easy to use (Muriyatmoko et al., 2018). Learning listening skills for Indonesian Language Students for Foreign Speakers (BIPA) is more effective using android-based teaching materials than learning that does not use (Mubarok \& Kartika, 2019). The Android-based flipbook teaching material is very valid and sifted worthy of being used to learn Arabic syntax (Fauzan et al., 2019). The average value of listening to students who learn to use teaching materials based on Android is more than 80 (Ariputri \& Supraptono, 2015).

Based on several reasons and the results of previous studies above, it is time for lecturing materials to be developed using the Android operating system to make it easier for students to access teaching materials and following the times The first stage in designing and developing language learning materials is a need analysis. In formal terms, need analysis (need assessment) defined as "the process of determining the need for which a learner or group of learners requires a language and arranging the need according to priorities. Needs assessment uses both subjective and objective information (e.g., data from questionnaires, tests, interviews, observations)." (Richards et al., 1986, p. 189). Need analysis is "an activity involved in gathering information that will serve as a basis for developing a curriculum that will meet the learning needs of cesrtain groups of students" (Brown, 1996, p. 35). Johns \& Dudley-Evans (1991) also argue that need analysis as the first step in curriculum design, which can provide validity and relevance for curriculum design activities.

Because of this situation, the main aim of the present study was to conduct a need analysis to know the student's need in istima $\bar{a}^{-}$(listening) III materials development, especially for learning materials based on android. The information about the result will guide the lecturers to design learning materials that will develop.

\section{Method}

There are many methods used in need analysis such as non-expert intuitions, surveys and questionnaires, interviews structured or unstructured, expert practitioner intuitions, language audits, participant observation and so on (Kim, 2013). This research employed questionnaire survey. The questionnaire includes target situation (condition) and learning materials development needs. The Participants in this study are 41 students of the 2018 academic year in the Arabic Language Education Study Program, Faculty of Languages and Arts, Universitas Negeri Jakarta. The 
Questionnaires are distributed through the google form application. All questionnaires distributed were answered and returned by students directly on the google form application. Descriptive and frequencies analysis were run in order to process the collected information.

\section{Results}

\section{Target Situation Analysis}

Target situation analysis aims to determine the possibility of the development of Android-based teaching materials on subjects istima $\bar{a}^{-}$III. Data collection is done through a questionnaire process through the presentation of questions that are answered "yes" or "no" and adverb of frequency. Researcher presents 6 questions: (1) Do you have a gadget with the Android operating system? (2) Are you a gadget user with the Android operating system? (3) Do you use these devices to support your learning? (4) How often do you use these gadgets to support your learning? (5) Do you use Android-based applications to support your learning? (6) How often do you use Android-based applications to support your learning? The response of these questions can be seen in the graphs below.

\section{Graph 1. The ownership status of Android status \\ The ownership status of Android devices}

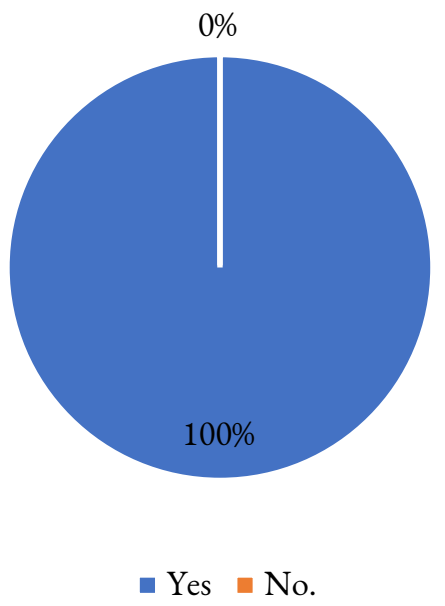

Graph 1 shows that all respondents have Android-based devices; this is the primary consideration of researchers to compile Android-based teaching materials. Besides, students are not only owners of Android devices, but also as active users of these devices. We can see this in the second graph below. 
Graph 2. Student status as an Android device user

Respondent status as an Android device user

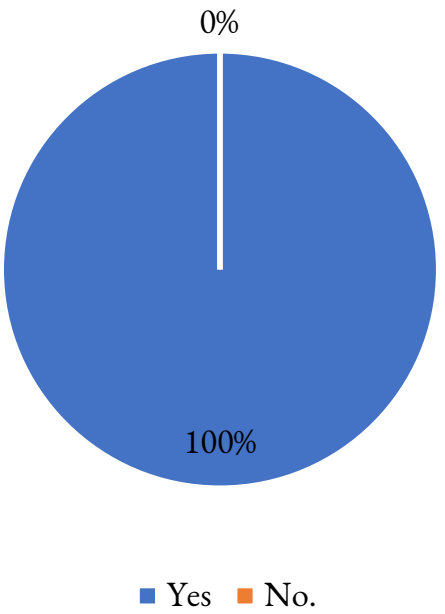

Another consideration that encourages researchers to compile Android-based teaching materials is that apart from being the owner and user of an Android device, students also use it as a learning support tool. This can be seen in the chart below.

Graph 3. The use of an android device as a learning support tool

The use of an android device as a learning support tool

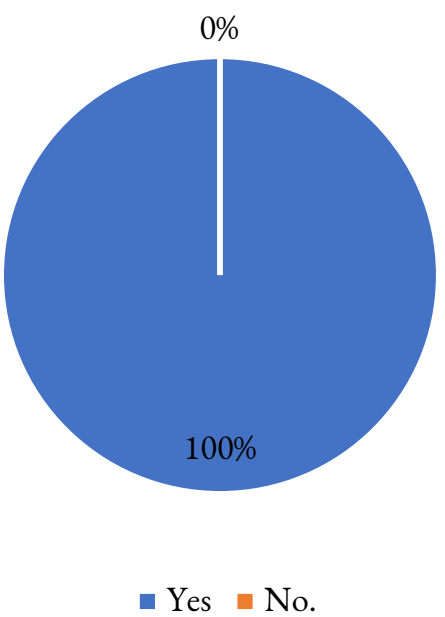

Based on data from graph 3 above, researchers are looking for more in-depth information about the intensity of students using Android devices as a means of supporting their learning. From this search, the data obtained, as illustrated in graph 4 below. 
Graph 4. The frequency of using android devices to support learning

The frequency of using android devices to support learning

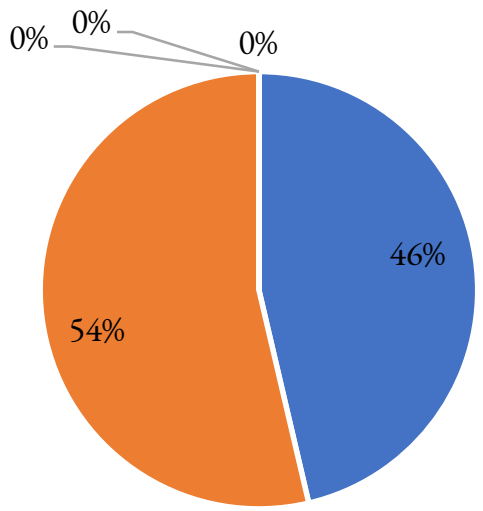

Always $\square$ Often $\square$ Sometimes $\square$ Seldom $\square$ Never

Graph 4 shows that $46 \%$ of students (19 persons) stated that they always use Android devices as a learning support tool. Meanwhile, the other $54 \%$ (22 persons) said that they often use your android device as a learning support tool. From these data, it can be concluded that students are accustomed to using Android-based devices as a tool, media, and learning material.

Besides being owners and users of Android devices, students are also accustomed to using various Android applications in their learning. This can be seen from the following graph 5 and 6.

Graph 5. The use of an android application as a learning support tool

The use of an android application as a learning support tool

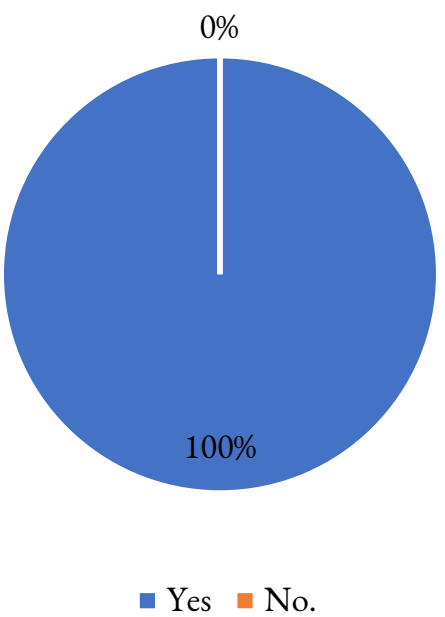

Based on graph 5 above, we can know that all students are accustomed to using android based applications in their learning activities. Furthermore, how often do they use the app in learning activities? 32\% of students (13 persons) always answered, 66\% of students (27 persons) said it often, and only $2 \%$ ( 1 persons) said sometimes. We can observe this data in graph 6 below. 
Graph 6. The frequency of using android application to support learning

The frequency of using android application to support learning

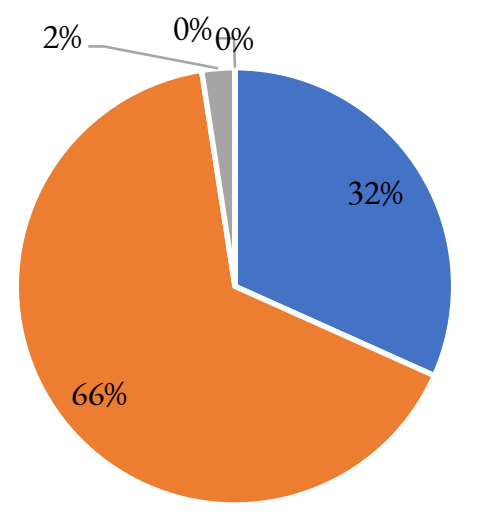

$\backsim$ Always $\backsim$ Often $\square$ Sometimes $\backsim$ Seldom $\square$ Never

Based on the data depicted on all the charts about the analysis of the target situation above. The findings in the first part of this show that researchers can develop Android-based teaching materials on subjects istimác III because all students have and use an android device and use the device as a support for their learning in high intensity.

Lacks and Wants Need Analysis

The following is a graphic presentation of lacks and wants needs analysis.

Graph 7. Respondents' statements about the difficulties of using Android-based devices to support learning Respondents' statements about the difficulties of using Android-based devices to support learning

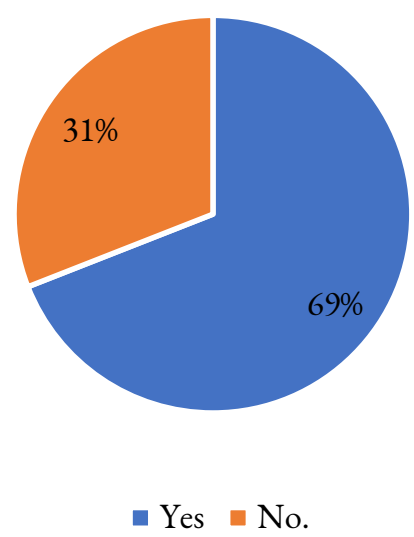

Graph 7 shows that even though students are used to using the application, 31\% of them stated that they still experienced problems, while $69 \%$ indicated that they did not experience problems. The 
difficulties faced by students in using Android applications in learning can be considered in the following graph 8.

Graph 8. Types of difficulties faced when using android applications in learning

Types of difficulties faced when using android applications in learning

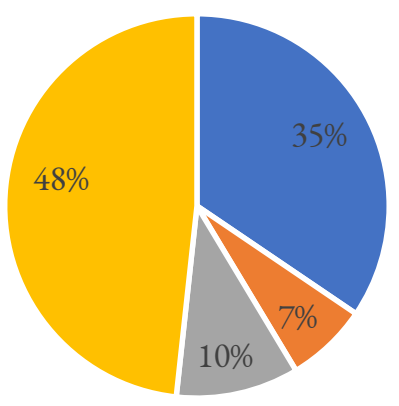

$$
\begin{aligned}
& \text { Low device specifications } \quad \text { Unsuitable application } \\
& \text { - Complex application to use } \quad \text { The size of a large application }
\end{aligned}
$$

Based on the graph 8 we know that most students (48\%) experienced problems using the android app in their learning because of the size of a large application, 35\% experienced difficulties due to low spec devices they have. Meanwhile, $10 \%$ of students stated that the problem arose because an application that is used is quite complicated, and $7 \%$ stated that the issues they face due to the application being used do not match the needs.

Graph 9. Respondents' statements about the existence of android-based teaching materials on subjects

$$
\begin{aligned}
& \text { Respondents' statements about the existence of android-based teaching } \\
& \text { materials on subjects }
\end{aligned}
$$

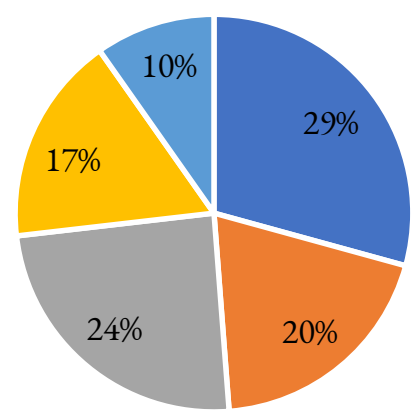

$$
\text { All of } \square \text { Most of } \square \text { Some of } \square \text { One of } \square \text { None of }
$$

Graph 9 shows that $29 \%$ of students answered that all studys had used Android-based teaching materials, $20 \%$ of students answered only most subjects, $24 \%$ of students answered only a small proportion, $17 \%$ of students answered only one or two studys that had already using Android-based 
teaching materials, and the remaining 10\% answered that none of the studys used Android-based teaching materials.

The variety of student answers shows that there is no teaching material available in Androidbased applications. It is possible that some students do not understand the meaning of the teaching material itself. They assume that the teaching materials here are all applications used to help their learning, not teaching materials prepared by the lecturers according to the applicable curriculum.

Graph 10. Student opinion about android-based teaching materials

Student opinion about android-based teaching materials

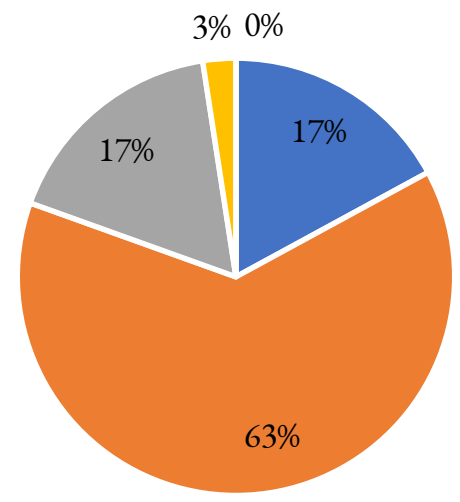

$\square$ Veri Agreed $\quad$ Agreed $\square$ Seldom $\square$ Not Agreed $\square$ Very Not Agreed

Graph 10 shows that $17 \%$ of students (7 persons) Very agreed if the teaching materials for a study are arranged in the form of an Android application, 63\% of students (26 persons) agreed, 17\% of students ( 7 persons) express seldom. Only 3\% (1 persons) Not agreed. From these data, it can be concluded that most students agree that the teaching materials in a study are presented in the form of Android-based application.

Graph 11. Student opinion about android-based teaching materials in istimā' III study

Student opinion about android-based teaching materials in istimā' III study

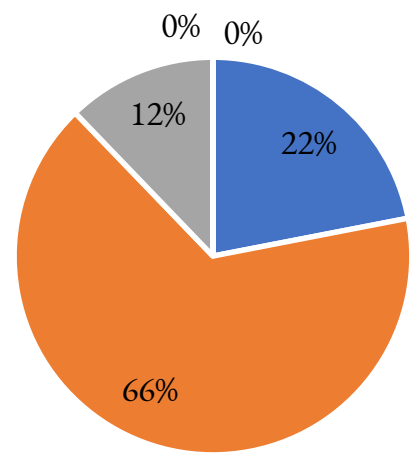

$\square$ Veri Agreed $\quad$ Agreed $\square$ Seldom $\square$ Not Agreed $\square$ Very Not Agreed 
Graph 11 shows that $22 \%$ of students ( 9 persons) stated very agreed the form of Android applications, $66 \%$ of students ( 27 persons) said agreed, and $12 \%$ of students ( 5 persons) are expressed seldom. From these data it can be concluded that most of the students agreed that if the teaching material in istima III study presented decided form of Android-based applications.

Graph 12. The possibility of respondents accessing android-based istima $\bar{a}^{-}$III learning materials

The possibility of respondents accessing android-based istimā' III learning materials

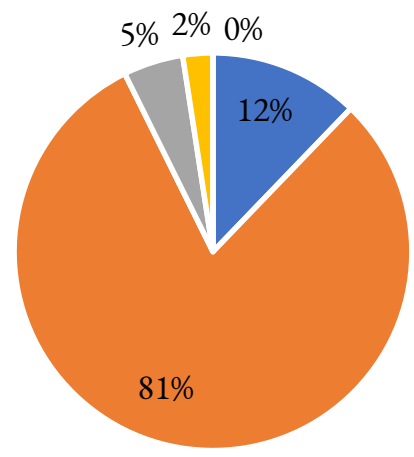

- Sure $\square$ Almost Sure $\square$ Posibble $\square$ Almost Impossible $\square$ Impossible

Graph 12 shows that $12 \%$ of students (5) must be able to access teaching materials istima $\bar{a}^{-}$III, if the teaching material is presented in the form of Android-based applications. Meanwhile, $81 \%$ of students ( 33 people) stated that they could access it. $5 \%$ of students ( 2 people) stated that it was possible to access it. The remaining $2 \%$ ( 1 person) stated that it was a bit difficult to access it. From these data, it can be concluded that most students can access istima $\bar{a}^{\prime}$ III teaching materials if the teaching materials are arranged in an android-based application.

Based on the data depicted in all the graphs about the above deficiency analysis. The findings of the second section indicate that there are no teaching materials that have been compiled in the form of an Android-based application, even though most students expect it.

\section{Discussion}

Based on data analysis shows that all students own and use an Android-based smartphone in their daily life. This phenomenon indicates two important things. First, current learning can migrate from conventional learning to mobile-based learning (M-learning). Second, it is necessary to provide Android-based learning materials.

M-learning refers to a set of technological devices, including smartphones, MP3 players and handheld computers that might have an impact on language learning (Dudeney \& Hockly, 2007). Meanwhile, Naismith et al define mobile learning as learning with wireless devices such as smartphone, personal digital assistant (PDA), iPod, palmtop, laptop, etc. (Naismith et al., 2004). Distinctive examples of the devices used for mobile learning include cell phones, smart phones, palmtops, and handheld computer, tablet PCs, laptops, and personal media players (Kukulska- 
Hulme \& Shield, 2008). Ally describes M-learning more specifically with “... the process of using a mobile device to access and study learning materials to communicate with fellow students, instructors or institution" (El Hariry, 2015).

The application of M-learning in education is predictable, some practitioners say that this learning model is a future learning model As Keegan anticipated, that "mobile learning is a harbinger of the future of learning" (Keegan, 2002). Therefore, it is not surprising that M-learning is already popular in some subjects such as languages (Traxler \& Kukulska-Hulme, 2007). However, the aim of implementing M-learning is not to challenge nor replace other forms of interactions (face-to-face in classrooms, lecture theatres and studios, or virtually in online learning environments): it is a supplementary method that can support, enrich and enhance students' learning experience.

Several researchers identified several reasons for the use of M-learning in education. Potentially, M-learning has many advantages for Foreign Language university students when it comes to learning foreign languages. One of the advantages could be the possibility to download certain English applications and programs that may help learners to improve their language skills, their language Muhammed systems like grammar and vocabulary and increase their awareness of such international tests such as TOEFL and IELTS. If a learner uses these applications, this might aid their English language experience (Muhammed, 2014).

M-learning might lead to motivation and encouragement for the participants, as it is highly likely that the smartphone applications improve their Foreign language (Hockly, 2013). Applications on mobile can also support a variety of pedagogical approaches, from traditional transmission and behaviorist approaches to communicative approaches (Kukulska-Hulme \& Shield, 2008). Based on these reasons, it is not surprising In their study, Darmi \& Albion (2014) They assert that the integration of mobile phones in second language teaching is acceptable to learners and has a significant role in improving language skills and related language areas.

With so many Android-based smartphone users, the M-Learning concept presented by Ally is perhaps more relevant today. In addition, although M-learning can be accessed by various devices, based on Prenski's research most students prefer to access M-learning via their smartphones. This is based on two reasons, first, many learning support applications can be used, both smartphones are portable and compatible (Taleb \& Sohrabi, 2012). Therefore, it is very natural that learning materials in this era are packaged in an Andorid-based mobile application which is portable and easily accessible anytime and anywhere.

\section{Conclusion}

The results of the study indicate that currently, Android-based teaching materials are required. This is based on two factors, namely internal and external factors. Internally, all students of the Arabic Language Education study program, Faculty of Languages and Arts, Universitas Negeri Jakarta have Android-based devices, besides that they are also active users of Android-based applications, so it is not surprising that all students agree with the plan to compile Android-based teaching materials. Externally, the current condition of the Covid-19 pandemic requires learning to be carried out online and the provision of Android-based teaching materials are one of the efforts to support the implementation of online learning. 


\section{References}

Ariputri, G. P., \& Supraptono, E. (2015). Peningkatan hasil belajar English Listening Skill dengan menggunakan aplikasi "Smarty Way" berbasis android. Edu Komputika Journal, 2(1), 38-47. doi:10.15294/edukomputika.v2i1.7834

Bennet, J. (2020, October 1). 23 Statistik mengagumkan pada internet dan media sosial di 2020. Wizcase. Retrieved from https://id.wizcase.com/blog/23-statistik-mengagumkan-padainternet-dan-media-sosial/

Brown, J. D. (1996). The elements of language curriculum: A systematic approach to program development. Boston: Heinle \& Heinle.

Darmi, R., \& Albion, P. (2014). A review of integrating mobile phones for language learning. $10^{\text {th }}$ International Conference on Mobile Learning.

Dudeney, G., \& Hockly, N. (2007). How to teach English with technology. Harlow: Pearson Education Limited.

El Hariry, N. A. H. (2015). Mobile phones as useful language learning tools. European Scientific Journal, 11(16), 298-317. Retrieved from http://eujournal.org/index.php/esj/article/view/5870

Fauzan, M., Dariyadi, M. W., \& Fara, E. W. (2019). Desain dan pengembangan bahan ajar flip book berbasis android untuk mata kuliah Tarkib Mukatstsaf Ibtida’i bagi mahasiswa Jurusan Sastra Arab Fakultas Sastra Universitas Negeri Malang. In Kreativitas dan inovasi dalam pembelajaran bahasa Arab di Indonesia. Prosiding Konferensi Nasional Bahasa Arab V Universitas Negeri Malang (pp. 343-361). Retrieved from http://prosiding.arabum.com/index.php/konasbara/article/view/504

Hockly, N. (2013). Mobile learning. ELT Journal, 67(1), 80-84. doi.org/10.1093/elt/ccs064

Indonesia digital 2019: Tinjauan umum. (2019). Websindo. Retrieved from https://websindo.com/indonesia-digital-2019-tinjauan-umum/

Johns, A., \& Dudley-Evans, T. (1991). English for specific purposes: International in scope, specific in purpose. TESOL Quarterly, 25(2), 297-314. doi:10.2307/3587465

Keegan, D. (2002). The future of learning: From eLearning to mLearning. ZIFF Papiere, 119. Fern Universitat, Hagen, Germany. Retrieved from https://eric.ed.gov/?id=ED472435

Kementerian Pendidikan dan Kebudayaan Republik Indonesia. (2016). Peraturan Menteri Pendidikan dan Kebudayaan Nomor 22 Tabun 2016 tentang Standar Proses Pendidikan Dasar dan Menengah. Retrieved from http://vervalsp.data.kemdikbud.go.id/prosespembelajaran/file/Permendikbud_Tahun20 16_Nomor022_Lampiran.pdf

Kim, H. H. (2013). Needs analysis for English for specific purpose course development for engineering students in Korea. International Journal of Multimedia and Ubiquitous Engineering, 8(6), 279-288. doi:10.14257/ijmue.2013.8.6.28

Kukulska-Hulme, A., \& Shield, L. (2008). An overview of mobile assisted language learning: From content delivery to supported collaboration and interaction. ReCALL, 20(3), 271-289. doi:10.1017/S0958344008000335

Mubarok, I. W., \& Kartika, P. C. (2019). Efektifitas penggunaan bahan ajar berbasis android Nemo bahasa Indonesia untuk mahasiswa BIPA tingkat pemula program darmasiswa Universitas Muhammadiyah Surabaya. Metalingua:Jurnal Pendidikan Babasa dan Sastra Indonesia, 4(1), 
19-24. doi:10.21107/metalingua.v4i1.6124

Muhammed, A. A. (2014). The impact of mobiles on language learning on the part of English Foreign Language (EFL) university students. Procedia - Social and Behavioral Sciences, 136, 104-108. doi:10.1016/j.sbspro.2014.05.297

Muriyatmoko, D., Abdullah, A. F., \& Musyafa, Z. A. (2018). Durus al-lughah Gontory: Interactive Arabic mobile learning for beginners. IJITEE (International Journal of Information Technology and Electrical Engineering), 2(1). doi:10.22146/ijitee.36641

Naismith, L., Sharples, M., Vavoula, G., \& Lonsdale, P. (2004). Literature review in mobile technologies and learning (Report, 11). Futurelab. http://telearn.archivesouvertes.fr/docs/00/19/01/43/PDF/Naismith_2004.pdf

Pelajar Indonesia jadi salah satu pengguna teknologi tertinggi di dunia. (2018, December 11). BBC News Indonesia. Retrieved from https://www.bbc.com/indonesia/majalah-46500293

Richards, J., Platt, J., Weber, H., \& Inman, P. (1986). Longman dictionary of applied linguistics. RELC Journal, 17(2), 105-110. doi:10.1177/003368828601700208

Taleb, Z., \& Sohrabi, A. (2012). Learning on the move: The use of mobile technology to support learning for university students. Procedia - Social and Behavioral Sciences, 69, 1102-1109. doi:10.1016/j.sbspro.2012.12.038

Traxler, J., \& Kukulska-Hulme, A. (Eds.). (2007). Mobile Learning: A Handbook for Educators and Trainers. London: Routledge https://doi.org/10.4324/9780203003428 